\title{
Circulating antibodies against corneal epithelium and hookworm in patients with Mooren's ulcer from Sierra Leone
}

\author{
R. VAN DER GAAG, ${ }^{1}$ H. ABDILlahi, ${ }^{1}$ J. S. STILMA, ${ }^{2}$ AND J. C. M. VETTER ${ }^{3}$ \\ From the 'Department of Ophthalmo-Immunology, Netherlands Ophthalmic Research Institute, Amsterdam; \\ ${ }^{2}$ Department of Ophthalmology, Free University of Amsterdam; and the ${ }^{3}$ Department of Parasitology, \\ University of Amsterdam and Institute of Tropical Hygiene, Royal Tropical Institute, Amsterdam
}

SUMMARY A relationship between the occurrence of Mooren's ulcer and hookworm infections was suggested by Kuriakose in 1963. Sixteen patients with clinical diagnosis of Mooren's ulcer and 15 local controls from Sierra Leone were tested with respect to serum immunoglobulin levels, circulating antibody to hookworm, circulating antibodies to corneal epithelium, stool smears, and eosinophil and lymphocyte levels. Both patients and healthy controls had circulating antibodies to corneal epithelium and to hookworm. In the controls the titres of hookworm antibodies were significantly lower than in the patients, though in both groups most people had intestinal parasite infestations as detected by the stool smear. Further investigation failed to demonstrate any other significant immune alteration in the patients as compared with local controls.

Mooren's ulcer is defined clinically as a chronic, painful, peripheral ulceration that has a steep, undermined, and occasionally infiltrated leading border and that advances round the periphery towards the centre of the cornea. There appear to be 2 types of this disease. The first occurs in young adults, runs a malignant course, is frequently bilateral and responds poorly to therapy. The second type runs a milder course, is often unilateral, more responsive to therapy, and occurs in the fourth decade of life or later. ${ }^{1}$ Mooren's ulcer of the first type seems to be the commoner in developing countries. ${ }^{2}$

The pathogenesis of Mooren's ulcer remains uncertain, though an autoimmune basis has been suggested for this disease. Circulating antibodies to corneal and conjunctival epithelium have been found in patients with Mooren's ulcer, ${ }^{34}$ and cellular immunity to corneal antigen has been described in some patients. ${ }^{5}$ Deposition of immunoglobulins and complement has been demonstrated by direct immunofluorescence on corneal ulcer and conjunctival biopsy specimens. ${ }^{6}$ These findings are suggestive of a secondary autoimmune disease, and

Correspondence to $\operatorname{Dr} R$. van der Gaag. The Netherlands Ophthalmic Research Institute, Department of OphthalmoImmunology, PO Box 6411, 1005 EK Amsterdam, The Netherlands. possible initiating factors might be: bacterial or viral infection,,$^{78}$ trauma, ${ }^{9}$ or helminthic disease.

A relationship between the occurrence of Mooren's ulcer and hookworm infection was first proposed by Kuriakose. ${ }^{10} \mathrm{He}$ suggested that the ulcer is the result of corneal sensitivity to a toxin elaborated by hookworms. Trojan ${ }^{11}$ supported this view from his observation of 34 Mooren's ulcer patients in Togo, and Majekodunmi ${ }^{12}$ reported similar findings in Nigeria. To date no immunological studies have been performed to test this hypothesis. Our purpose in this respect was to investigate humoral immunity in 16 Mooren's ulcer patients and in 15 controls from Sierra Leone and to look for evidence of cross-reacting immunity between hookworm and corneal antigens.

\section{Materials and methods}

Sera were collected in Sierra Leone from 16 patients with clinically defined Mooren's ulcer and from 15 controls. The controls were patients who came to Lunsar Eye Hospital for refraction or minor complaints. They were included in this series only if they had no corneal abnormalities. Patients and controls were matched as near as possible for age, sex, and tribal origin. 
Both groups were examined ophthalmologically. A leucocyte count was done and the stools were screened for parasite eggs. A blood sample was drawn, allowed to clot, and the separated serum was frozen and stored at $-20^{\circ} \mathrm{C}$ until it was shipped to Amsterdam. Immunoglobulin G, M, and A levels were determined by radial immunodiffusion assay, ${ }^{13}$ and immunoglobulin $E$ levels were determined by a radioimmunosorbent assay. ${ }^{14}$

Antibodies against hookworm were detected by an indirect immunofluorescence technique on a heterologous antigen. The infective stage of Ancylostoma caninum (L3 stage) was obtained as described previously. ${ }^{15}$ To see positive fluorescence the metabolism of the larvae had to be arrested. ${ }^{16}$ This was done by incubating the larvae for 1 hour with $20 \mathrm{mM}$ sodium azide in phosphate buffered saline
(PBS), $\mathrm{pH} 7 \cdot 2$, before and throughout the test. The larvae so treated were incubated with serum dilutions for one hour at $37^{\circ} \mathrm{C}$. After thorough washing with PBS containing sodium azide the larvae were incubated for one hour at $37^{\circ} \mathrm{C}$ with a $1 / 20$ dilution of fluorescein isothiocyanate (FITC) labelled swine anti-human immunoglobulin $G$ (Nordic). After the excess labelled antibody had been washed off, one drop of suspension was put on a glass slide and viewed with a Leitz fluorescence microscope with epiillumination. The antibody titre was expressed as the last serum dilution to show positive fluorescence.

Circulating antibodies against corneal epithelium were assayed by an indirect immunofluorescence technique on rabbit corneas. The corneas were snap frozen, sections were cut at $4 \mu \mathrm{m}$, air dried on gelatin coated slides, and fixed in acetone for 10 minutes.

Table 1 Immunoglobulin levels, Ancylostoma caninum antibody titres, and corneal epithelium antibodies in 16 Mooren's ulcer patients and 15 local controls from Sierra Leone, West Africa

\begin{tabular}{|c|c|c|c|c|c|c|c|c|}
\hline \multirow[t]{2}{*}{ Patients } & \multirow[t]{2}{*}{ Sex } & \multirow[t]{2}{*}{ Age } & \multicolumn{4}{|l|}{$I U / m l$} & \multirow{2}{*}{$\begin{array}{l}\text { Ancylostoma } \\
\text { caninum } \\
\text { reciprocal antibody } \\
\text { dilution }\end{array}$} & \multirow{2}{*}{$\begin{array}{l}\text { Corneal epithelium } \\
\text { antibodies }\end{array}$} \\
\hline & & & $\lg A$ & $I g M$ & $\lg G$ & $\operatorname{Ig} E$ & & \\
\hline 1 & $\mathbf{M}$ & 16 & ND & 446 & 295 & 460 & 40 & - \\
\hline $2^{*}$ & F & 18 & 130 & 500 & 360 & 3680 & 5120 & + \\
\hline 2 & & & 91 & 362 & 273 & 4200 & 2560 & + \\
\hline $3^{*}$ & $\mathbf{M}$ & 21 & 81 & 137 & 158 & 11080 & 2560 & + \\
\hline 4 & $\cdot \mathbf{F}$ & 23 & 149 & 264 & 295 & 6300 & 1280 & + \\
\hline 5 & $\mathbf{M}$ & 24 & 90 & 190 & 240 & 1280 & 40 & + \\
\hline $6^{*}$ & F & 26 & 118 & 583 & 198 & 2040 & 80 & + \\
\hline 7 & $\mathbf{M}$ & 29 & 250 & 310 & 250 & 2220 & 320 & + \\
\hline 8 & $\mathbf{M}$ & 30 & 90 & 380 & 230 & 2190 & 640 & - \\
\hline 9 & $\mathbf{M}$ & 32 & 128 & 211 & 250 & 5880 & 40 & + \\
\hline 10 & $\mathbf{F}$ & 35 & 93 & 209 & 243 & 260 & 40 & + \\
\hline 11 & $\mathbf{M}$ & 37 & 162 & 312 & 303 & 11730 & 1280 & - \\
\hline $12^{*}$ & $\mathbf{F}$ & 38 & 190 & 211 & 205 & 2300 & 2560 & + \\
\hline 13 & $\mathbf{M}$ & 38 & 93 & 185 & 268 & 6300 & 40 & + \\
\hline 13 & & & 86 & 185 & 218 & 4700 & 1280 & + \\
\hline 14 & $\mathbf{M}$ & 40 & 151 & 206 & 245 & 670 & 40 & + \\
\hline 15 & $\mathbf{M}$ & 40 & 278 & 296 & 328 & 9030 & 320 & + \\
\hline 16 & $\mathbf{F}$ & 60 & 230 & 256 & 275 & 270 & $>640$ & + \\
\hline \multicolumn{9}{|l|}{ Controls } \\
\hline 1 & $F$ & 20 & 180 & 280 & 240 & 2540 & 20 & + \\
\hline 2 & $\mathbf{M}$ & 20 & 81 & 238 & 250 & 4300 & 160 & + \\
\hline 3 & $\mathbf{F}$ & 21 & 114 & 251 & 185 & 180 & 40 & + \\
\hline 4 & $\mathbf{F}$ & 22 & 135 & 477 & 183 & 6090 & 10 & - \\
\hline 5 & $\mathbf{M}$ & 25 & 130 & 240 & 250 & 3770 & 20 & + \\
\hline 6 & $\mathbf{F}$ & 25 & 104 & 193 & 255 & 2100 & 640 & + \\
\hline 7 & $\mathbf{M}$ & 25 & 70 & 190 & 438 & 1400 & 40 & + \\
\hline 8 & $\mathbf{M}$ & 26 & 109 & 190 & 550 & 14000 & 40 & + \\
\hline 9 & $\mathbf{M}$ & 28 & 100 & 120 & 240 & 1370 & 80 & - \\
\hline 10 & $\mathbf{M}$ & 29 & 118 & 243 & 183 & 4600 & $>640$ & + \\
\hline 11 & $\mathbf{M}$ & 31 & 170 & 360 & 470 & 24000 & 80 & + \\
\hline 12 & $\mathbf{M}$ & 40 & 81 & 180 & 258 & 1400 & 40 & + \\
\hline 13 & $\mathbf{M}$ & 45 & 128 & 119 & 285 & 16830 & 80 & + \\
\hline 14 & $\mathbf{F}$ & 66 & 144 & 243 & 175 & 450 & 5120 & + \\
\hline 15 & $\mathbf{F}$ & & 146 & 219 & 408 & 2700 & 80 & ND \\
\hline \multirow{2}{*}{\multicolumn{3}{|c|}{$\begin{array}{l}\text { Normal Dutch } \\
\text { donors }\end{array}$}} & & & & & & \\
\hline & & & $40-225$ & $45-335$ & $65-200$ & $<100$ & $<10$ & $5.6 \%$ positive \\
\hline
\end{tabular}

*Patients with bilateral Mooren's ulcer. ND=not detected. 
After being washed with PBS the tissues were overlaid with a $1 / 10$ dilution of serum and incubated at room temperature for 30 minutes. The slides were washed with PBS and incubated for 30 minutes in the dark with fluorescein labelled goat anti-human immunoglobulin (Nordic), diluted 1/40 with PBS. The tissues were washed thoroughly and covered with a solution of $90 \%$ glycerin and $10 \%$ PBS containing $100 \mathrm{mg} p$-phenylenediamine per $10 \mathrm{ml} .{ }^{17}$ This solution prevents fading of fluorescence when the sections are scored with a Leitz fluorescence microscope.

To determine whether there is any cross-reactivity between hookworm antigens and corneal antigens absorption studies were performed. $100 \mu \mathrm{l}$ serum positive for corneal epithelium and hookworm was incubated for 90 minutes at room temperature with $3 \times 10^{5}$ rabbit corneal epithelium cells. After centrifugation the supernatant was tested for antibodies against corneal epithelium and against hookworm.

To eliminate hookworm antibodies $200 \mu \mathrm{l}$ serum, positive for both antigens, was incubated for 90 minutes at $37^{\circ} \mathrm{C}$ with $1 \times 10^{3}$ Ancylostoma caninum L3 stage. After centrifugation the supernatant was tested for hookworm and corneal epithelium antibodies.

Statistical analysis of the data was performed by Student's $t$ test and the chi-square test.

\section{Results}

Immunoglobulin levels. Immunoglobulin $\mathrm{G}$ and $\mathrm{E}$ were increased in all the patients and all the controls. Immunoglobulin $\mathrm{M}$ was increased in 5 patients and 2 controls, and immunoglobulin A was increased only in 3 patients. Compared with levels normal in the Netherlands, increased immunoglobulin levels were common in West Africans. There was, however, no significant difference $(p>0.5)$ between the patients and the controls for any of the immunoglobulins tested (Table 1).

Antibodies to Ancylostoma caninum L3 stage. With this assay a titre of $1 / 10$ or less is considered negative for Dutch sera. All the Mooren's ulcer patients and all but one control were found to have antibodies to Ancylostoma caninum L3 stage. The titres, however, were higher in patients than in controls. This difference was significant $\left(\chi^{2}=3 \cdot 87\right.$, $p=0.05$ ) when the cut off point was taken at a titre of $1 / 80$ or less. Furthermore, 3 out of 4 patients with bilateral Mooren's ulcer had titres of $1 / 640$ or over (Table 1).

Antibodies to corneal epithelium. Circulating antibodies to corneal epithelium were found in surprisingly high numbers in both the patient and the control groups (Table 1). Corneal epithelium antibodies were present in 13 out of 16 Mooren's ulcer patients and in 13 out of 15 controls (Table 1 ). The circulating antibodies were specific for corneal epithelial cells, the corneal stroma and endothelium cells showing no fluorescence above background. The finding that circulating antibodies occurred in so many normal Sierra Leoneans was very surprising. Furthermore, corneal epithelium antibodies found in some of the patients' sera and in some of the controls' sera produced a different fluorescence pattern from that found with Dutch sera containing corneal epithelium antibodies, which might be due to the fact that the sera also contain other autoantibodies (Fig. 1).
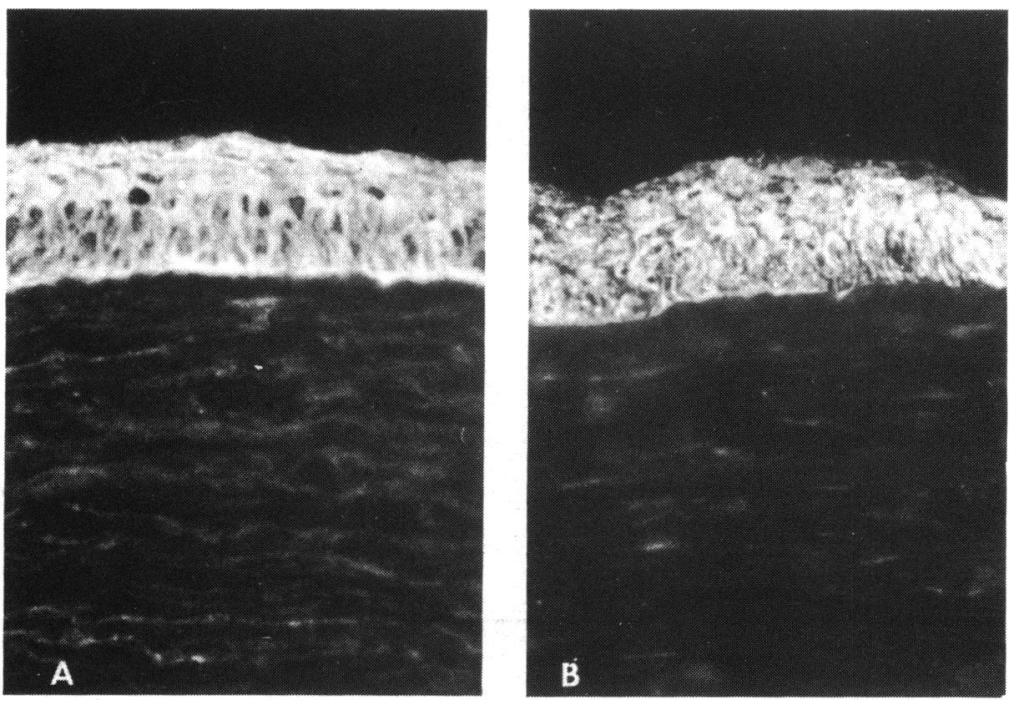

Fig. 1 (A) Antibodies to the cytoplasm of corneal epithelium as demonstrated by the indirect immunofluorescent techniques in the serum of a patient suffering from Mooren's ulcer. (B) Different fluorescence pattern found with the serum of some of Mooren's ulcer patients and some of the local controls. 
Table 2 Absorption studies to determine the degree of cross-reactivity between hookworm and corneal antigens

\begin{tabular}{|c|c|c|c|c|c|}
\hline \multirow[t]{2}{*}{ Serum } & \multirow{2}{*}{$\begin{array}{l}\text { Absorbed } \\
\text { with: }\end{array}$} & \multicolumn{2}{|c|}{ Corneal epithelium antibodies } & \multicolumn{2}{|c|}{ Ancylostoma caninum antibodies } \\
\hline & & Before absorpt. & After absorpt. & Before absorpt. & After absorpt. \\
\hline 7 & $\begin{array}{l}\text { Rabbit cornea epithelium } \\
\left(3 \times 10^{5} \text { cells }\right)\end{array}$ & + & - & 320 & 320 \\
\hline 7 & $\begin{array}{l}\text { Ancylostoma caninum L3 } \\
\text { stage }\left(1 \times 10^{3}\right)\end{array}$ & + & + & 320 & 0 \\
\hline 15 & $"$ & + & + & 320 & 0 \\
\hline 10 & $"$ & + & + & $>640$ & 0 \\
\hline 5 & $"$ & + & + & 20 & 0 \\
\hline
\end{tabular}

Absorption studies. To determine whether there is any antigenic determinant in common between hookworm antigens and corneal epithelium antigens some sera positive for both antigens were absorbed with Ancylostoma caninum L3 stage and one serum with scraped rabbit corneal epithelium. In both tests the antibodies to the absorbing antigen were completely removed without affecting the reactivity to the other antigen (Table 2).

Stool examination. Hookworm eggs were commonly found both in Mooren's ulcer patients and in controls (Table 3 ). In fact only 2 patients and 5

Table 3 Clinical investigations in 16 Mooren's ulcer patients and 14 local controls from Sierra Leone, West Africa

\begin{tabular}{|c|c|c|c|c|c|c|c|c|c|}
\hline Patients & Sex & Age & $\begin{array}{l}\text { Ulcus, } \\
\text { duration }\end{array}$ & $\begin{array}{l}\text { Affected } \\
\text { eye }\end{array}$ & $\begin{array}{l}\text { Iris } \\
\text { prolapse }\end{array}$ & $\begin{array}{l}\text { Skin } \\
\text { snip }\end{array}$ & $\begin{array}{l}\text { Stool } \\
\text { examination }\end{array}$ & $\begin{array}{l}\text { Differe } \\
\text { blood } \\
\% \text { eo }\end{array}$ & $\begin{array}{l}\text { ntial } \\
\text { ount } \\
\% \text { ly }\end{array}$ \\
\hline 1 & $\mathbf{M}$ & 16 & 1 (month) & $\mathbf{R}$ & - & - & Ascaris & 4 & 62 \\
\hline 2 & $\mathbf{F}$ & 18 & 1 & $\mathbf{R}+\mathbf{L}$ & - & - & $\begin{array}{l}\text { Ancylostoma + } \\
\text { schistosoma }\end{array}$ & 5 & 46 \\
\hline 2 & & & 2 & $\mathbf{R}+\mathbf{L}$ & - & - & Ancylostoma & 6 & 35 \\
\hline 3 & $\mathbf{M}$ & 21 & 1 & $\mathrm{R}+\mathrm{L}$ & + & - & Schistosoma & 14 & 33 \\
\hline 4 & $\mathbf{F}$ & 23 & 1 & $\mathrm{~L}$ & + & - & Ascaris & 15 & 61 \\
\hline 5 & $\mathbf{M}$ & 24 & 2 & $\mathrm{~L}$ & + & - & Negative & 11 & 38 \\
\hline 6 & $\mathbf{F}$ & 26 & 12 & $\mathrm{R}+\mathrm{L}$ & + & - & Ancylostoma & 4 & 25 \\
\hline 7 & $\mathbf{M}$ & 29 & 1 & $\mathrm{~L}$ & - & - & Negative & 17 & 51 \\
\hline 8 & $\mathbf{M}$ & 30 & 3 & $\bar{L}$ & - & - & Ancylostoma & 24 & 48 \\
\hline 9 & $\mathbf{M}$ & 32 & 2 & $\mathbf{R}$ & - & + & Ancylostoma & 11 & 47 \\
\hline 10 & $\mathrm{~F}$ & 35 & 4 & $\mathbf{L}$ & + & - & Trichiuris & 3 & 40 \\
\hline 11 & $\mathbf{M}$ & 37 & 2 & $\mathbf{R}$ & - & - & Ancylostoma & 13 & 46 \\
\hline 12 & $\mathbf{F}$ & 38 & $1 / 2$ & $\mathbf{R}+\mathrm{L}$ & - & - & Ancylostoma & 3 & 65 \\
\hline 13 & $\mathbf{M}$ & 38 & 1 & $\mathbf{R}$ & - & - & Schistosoma & 6 & 30 \\
\hline 13 & & & 3 & $\mathbf{R}$ & - & - & Ancylostoma & 5 & 54 \\
\hline 14 & $\mathbf{M}$ & 40 & 3 & L & - & + & Ancylostoma & 2 & 35 \\
\hline 15 & $\mathbf{M}$ & 40 & 2 & $\mathbf{R}$ & - & + & Ancylostoma & 1 & 49 \\
\hline 16 & $\mathbf{F}$ & 60 & 1 & $\mathbf{R}$ & - & + & Ancylostoma & 2 & 31 \\
\hline \multicolumn{10}{|l|}{ Controls } \\
\hline 1 & $\mathrm{~F}$ & 20 & & & & ND & $\begin{array}{l}\text { Ancylostoma } \\
+ \text { ascaris }\end{array}$ & 6 & 50 \\
\hline 2 & $\mathbf{M}$ & 20 & & & & - & Ancylostoma & 29 & 35 \\
\hline 3 & $\mathrm{~F}$ & 21 & & & & - & Schistosoma & 3 & 35 \\
\hline 4 & $\mathbf{F}$ & 22 & & & & - & Negative & 4 & 51 \\
\hline 5 & $\mathbf{M}$ & 25 & & & & ND & $\begin{array}{l}\text { Ancylostoma } \\
+ \text { ascaris }\end{array}$ & 10 & 46 \\
\hline 6 & $\mathbf{F}$ & 25 & & & & - & Ancylostoma & 25 & 34 \\
\hline 7 & $\mathbf{M}$ & 25 & & & & - & Negative & 6 & 14 \\
\hline 8 & $\mathbf{M}$ & 26 & & & & + & Ancylostoma & 7 & 35 \\
\hline 9 & $\mathbf{M}$ & 28 & & & & ND & Ancylostoma & 14 & 42 \\
\hline 10 & $\mathbf{M}$ & 29 & & & & - & Ancylostoma & 14 & 42 \\
\hline 11 & $\mathbf{M}$ & 31 & & & & ND & Negative & 20 & 48 \\
\hline 12 & $\mathbf{M}$ & 40 & & & & - & Negative & 9 & 50 \\
\hline 13 & $\mathbf{M}$ & 45 & & & & - & Trichiuris & 9 & 50 \\
\hline $\begin{array}{l}14 \\
15\end{array}$ & $\begin{array}{l}\mathbf{F} \\
\mathbf{F}\end{array}$ & 66 & & & & - & Negative & 4 & 33 \\
\hline
\end{tabular}

* Skin snip for oncocerca detection.

$\mathrm{ND}=$ not done 
controls were free of intestinal parasites, other parasites found being Ascaris spp., Schistosoma spp., and Trichiuris spp.

Differential leucocyte count. The percentage eosinophilic granulocytes and lymphocytes was established in patients and in controls. Approximately half the people in each group had eosinophilia and/or lymphocytosis by European standards (Table 3 ). However, there was no difference between values found in Mooren's ulcer patients and in controls $(\mathrm{p}>0.5)$.

\section{Discussion}

Mooren's ulcer is a precisely defined clinical entity of unknown aetiology. There appear to be 2 types, and the cases described in this study were of the more severe form usually occurring in younger people and relatively unaffected by any kind of medical or surgical treatment. Many reports from West Africa describe similar severe cases, ${ }^{11} 1218$ and a hypothesis has been put forward that there is a cause-and-effect relationship between this type of Mooren's ulcer and the presence of a hookworm infection. ${ }^{10}$

The results of our investigations show that circulating antibodies to hookworm (L3 stage) were found both in Mooren's ulcer patients and in local controls. The only difference between the 2 groups was that the antibody titres in patients were generally higher than those found in the controls, although intestinal infestation, checked by a stool smear, occurred to the same extent in both groups. The present results neither confirm nor rule out the hypothesis ${ }^{10}$ that hookworm infestation might be a causative factor of Mooren's ulcer. We cannot at present rule out the initiating role of the following factors: other-stage specific hookworm antibodies, other hookworm species, and other specific antibodies or hookworm toxins. Furthermore, we could not investigate in this series the role of hookworm antibodies belonging to immunoglobulin classes other than IgG or the involvement of cellular immunity.

Circulating antibodies to corneal epithelium have been found in many patients with Mooren's ulcer ${ }^{3419}$ but only in 11 out of $195(5.6 \%)$ normal healthy Dutch blood donors of blood group 0 , rhesus positive (H. G. M. Geertzen, personal communication). These antibodies to corneal epithelium do not crossreact with smooth muscle, parietal cells, thyroid, conjunctival epithelium, lens epithelium, or oesophagus epithelium. In the present study we found that $81 \%$ of the Mooren's ulcer patients and $87 \%$ of the local controls had circulating antibodies to rabbit corneal epithelium. An increased incidence of autoantibodies such as rheumatoid factor, cold agglutinins, antinuclear factor, and organ specific autoantibodies against liver, kidney, heart, parietal cells, and thyroid has been reported in many so-called healthy individuals living in the tropics. ${ }^{20}$ Epidemiological evidence $^{2122}$ suggests that malaria plays a role in the production of these antibodies.

There is some evidence that malaria and trypanosomiasis ${ }^{2324}$ induce polyclonal activation of B lymphocytes. Malaria and Trypanosoma gambiense are both endemic in Sierra Leone. Therefore both the nonspecific increase of immunoglobulins $G$ and $E$ as well as the occurrence of corneal epithelium autoantibodies in the healthy controls might possibly be attributed to this polyclonal $\mathrm{B}$ cell activation. The question remains, however, whether the observed corneal epithelium antibodies have been elicited by corneal antigens or are the result of stimulation with an unknown cross-reacting antigen. The experimental results up to now do not suggest that hookworm antigens (L3 stage of Ancylostoma caninum) are implicated.

Studies are still in progress further to characterise these corneal epithelium antibodies, because the immunofluorescence pattern found with some of the patients' and controls' sera is different from that found in the Dutch sera containing corneal epithelium antibodies. Another reason for suspecting that the aetiology of Mooren's ulcer in West Africa might be different from that in temperate areas is that the high immunoglobulin A levels found in many Mooren's ulcer patients ${ }^{48}$ were seen in only 3 out of 16 patients in this series.

Further clinical and experimental work in this field might reveal whether circulating antibodies to cornea epithelium, induced by an as yet unknown agent, predispose healthy individuals to Mooren's ulcer when the intact barrier of the epithelium is modified in some way.

We thank Dr H. G. M. Geertzen and Professor T. E. W. Feltkamp (Department of Autoimmune Diseases, Central Laboratory of the Netherlands Red Cross Blood Transfusion Service) for their help and suggestions concerning the detection of corneal antibodies. We thank Mrs J. C. M. Beentjes for skilled secretarial assistance.

\section{References}

1 Brown SI. What is Mooren's ulcer? Trans Ophthalmol Soc UK 1978; 98: $390-2$.

2 Smolin G, O'Connor GR. Ocular immunology. Philadelphia: Lea and Febiger. 1981: 169-231.

3 Schaap OL, Feltkamp TEW, Breebaart AC. Circulating antibodies to corneal tissue in a patient suffering from Mooren's ulcer (ulcus rodens corneae). Clin Exp Immunol 1965; 5: 365-70.

4 Brown SI, Mondino BJ, Rabin BS. Autoimmune phenomenon in Mooren's ulcer. Am J Ophthalmol 1976; 82: 835-40.

5 Mondino BJ, Brown SI, Rabin BS. Cellular immunity in Mooren's ulcer. Am J Ophthalmol 1978; 85: 788-91.

6 Foster CS, Kenyon KR, Greiner J, Greineder DK, Frieland B, Allansmith MR. The immunopathology of Mooren's ulcer. Am J Ophthalmol 1979; 88: 149-59. 
7 Mondino BJ. Peripheral corneal ulcers and thinning disorders. Perspect Ophthalmol 1980; 4: 9-15.

8 Sie-Boen-Lian, Li-Shao-Chen. The possibility of a virus etiology of rodent corneal ulcer (Mooren). Ophthalmologica 1960; 10: 311-22.

9 Wood TO, Kaufman HE. Mooren's ulcer. Am J Ophthalmol 1971; 71: 417-22.

10 Kuriakose ET. Mooren's ulcer. Am J Ophthalmol 1963; 55: 1064-9.

11 Trojan HJ. Ulcus rodens (Mooren) - Aspekte der Ätiologie, des Verlaufs und der Therapie. Klin Monatsbl Augenheilkd 1979; 174: 166-76.

12 Majekodunmi AA. Ecology of Mooren's ulcer in Nigeria. Doc Ophthalmol 1980; 49: 211-9.

13 Fahey JL, McKelvey EM. Quantitative determination of serum immunoglobulins in antibody agar plates. $J$ Immunol 1965; 94: 84-90.

14 Adkinson NF. Measurement of total serum immunoglobulin E and allergen specific immunoglobulin $\mathrm{E}$ antibody. In: Rose NR. Friedman H, eds. Manual of clinical immunology. Washington: American Society for Microbiology, 1980: 794-807.

15 Klaver-Wesseling JCM, Vetter JCM, Visser WK. A comparative in vitro study of antibody binding to different stages of hookworm Ancylostoma caninum. Z Parasitenkd 1978; 56: 147-57.

16 Vetter JCM, Klaver-Wesseling JCM. IgG antibody binding to the outer surface of infective larvae of Ancylostoma caninum. Z Parasitenkd 1978; 58: 91-6.
17 Johnson GD, Gloria M, Aranjo CN. A simple method of reducing the fading of immunofluorescence during microscopy. $J$ Immunol Methods 1981; 43: 349-50.

18 Kietzman B. Mooren's ulcer in Nigeria. Am J Ophthalmol 1968; 65: 679-85.

19 Mondino BJ, Brown SI, Rabin BS. Autoimmune phenomena of the external eye. Ophthalmology 1978; 85: 801-17.

20 Greenwood BM, Whittle HC. Immunology of medicine in the tropics. Current topics in immunology series 14. London: Arnold, 1980: 1-21.

21 Shaper AG, Kaplan MH, Mody NJ, McIntyre PA. Malaria antibodies and autoantibodies to heart and other tissues in the immigrant and indigenous people of Uganda. Lancet 1968; ii: 1021-3.

22 Voller A, Lelijveld J, Matola YG. Immunoglobulin and malarial indices at different altitudes in Tanzania. $J$ Trop Med Hyg 1981; 74: 45-52.

23 Ruitenberg EJ, Buys J. Immunological aspects of some parasitic infections. Vet Quarterly 1980; 2: 166-75.

24 Terry RJ, Hudson KM, Faghihi-Shirazi M. Polyclonal activation by parasites. In: van den Bossche $H$, ed. The host-invader interplay. Proceedings of the 3rd international symposium on the biochemistry of parasites and host parasite relationships. Amsterdam, New York, Oxford: Elsevir North Holland, 1980: 259-71. 